\title{
Study on Modern Pottery Design in Urban Landscape
}

\author{
Jiming Lang \\ Eastern International Art College \\ Zhengzhou University of Light Industry \\ Zhengzhou, China
}

\begin{abstract}
In the design of urban landscape, application of modern pottery can make us achieve good design effects and enrich the form and content of urban landscape design. Various modern ceramic works, such as environmental facilities of pottery, pottery murals, pottery sculpture, are applied in the landscape design in our cities more and more widely. This paper briefly described the advantages and limitations of modern pottery in urban landscape design, as well as the common representation form of modern pottery in urban landscape design.
\end{abstract}

Keywords - modern pottery; urban landscape; design

\section{INTRODUCTION}

In the current competitive market economy, people have high tension in their living and they have more and more functional requirements for the space of urban landscape so the space of urban landscape should have not only its practical function but also spiritual and cultural infection function. In order to effectively enhance the urban living environment and further promote the urban development, all the urban constructors attach great importance to the design and construction of landscape environment. Good urban landscape design can improve the urban ecological environment and promote the harmonious development between man and nature. Currently, modern pottery is applied in urban landscape design more and more widely and its representation form is diverse. Due to its special properties, modern pottery has a unique advantage in the urban landscape space.

\section{THE AdVANTAgES AND Limitations OF MODERN POTTERY IN URBAN LANDSCAPE DESIGN}

\section{A. Physical Advantages of Modern Pottery}

First, modern pottery, directly made of natural clay, has ecological environmental protection and provides active use of industrial waste in cities, such as: coal flyash and kaolin mine tails, so it has the characteristics of no radiation and no pollution. Soil is the main raw material of modern pottery, by which we can create a variety of contemporary pottery works. compared with the art works made of stone and wood modern pottery has a higher degree of freedom in modelling, and has easy handling and long preservation [1].

Secondly, modern pottery has good stability and long preservation in the outdoor environment. It is anti-corrosion, waterproof and fireproof, nondeformable for ever, firm and durable, weathering resistant and light resistant. Moreover, even exposing to the weather, the pottery material is still able to maintain bright color and stable shape. People can appreciate in a close range and touch the modern pottery works in public environment, so that it shortens the distance between the public and the urban landscape and meets the psychological needs of citizens to familiarize the nature.

Finally, modern pottery has a good plasticity. As the soil itself has a good plasticity, the modern pottery works with soil as raw material has strong liberty and plasticity. wet die is punctured, carved, cut, kneaded and stamped before fired to achieve various texture effects, and it has large space of plasticity in comparison with other materials such as glass, stone, wood, cement. Due to the strong plasticity of raw material, various patterns can be shaped, with rich implication, and so modern pottery has the artistic characteristics of variety, rusticity and naturalness, enabling urban landscape design to have a large performance space.

\section{B. The Aesthetic Advantages of Modern Ceramics}

Aesthetic advantages of modern pottery are mainly reflected in two aspects of glaze and texture. From the glaze, modern pottery has rich glaze to make it have a good visual effects, among which crack glaze, matte glaze, transparent glaze and a variety of color glaze all have good color performance. In the production process, the glaze may also produce the unexpected artistic effects such as fambe, hacking, crackle, mottling, which bring the urban landscape more passion and the color more brightness and spring. From the texture, modern pottery industry has its formal beauty of which an important part is the material texture effect. Modern pottery texture has its beauty of interaction, interlace, density, thickness, overlapping, continuum and rhythm, giving the urban landscape space more association of rich space and texture, and further making the urban residents feel the warm, gentle and rustic earth [2].

\section{The Cultural Advantages of Modern Pottery}

The active application of modern pottery works in the urban landscape design can show the unique artistic charm of our pottery works, and even make it become a kind of cultural characteristics in the local area. Our pottery has a long history and profound connotations, and has strong cultural characteristics in the course of development. The subject matters of works mainly come from local folklore, mostly figures and animals, therefore pottery works is able to add more artistic content and cultural quality for the urban 
landscape and meet the demand of urban residents for environmental culture. At the same time, for modern pottery has a good plasticity, it can blend the spirit of a city, the modern spirit and the characteristics of the times into modern pottery works, showing the spirit of the times.

\section{The Limitations of Modern Pottery}

Modern pottery also showed some limitations in the process of participating in urban landscape design. First, the raw material of modern pottery is generally clay, quartz and feldspar, with unyielding and fragile quality. Once getting collision with hard objects, pottery works is easily fragmented shattered and damaged. Most urban landscapes are in the public area, which may bring some security risks for the fragility of modern pottery. Project construction, traffic accidents or vandalism will result in the fragmentation of some pottery works in urban landscape, and the fragments left on the road may cause injury of passers. Secondly, pottery works has uncertainty, and fambe may make works produce unpredictable change of surface effects, which is an important characteristic of pottery. But the urban landscape design must keep the consistency and standard of glaze of entire pottery works, which requires repeated firing, taking a long production time. Finally, the production of modern pottery works has complex processes, and high technology is required [3].

\section{THE REPRESENTATION FORM OF MODERN POTTERY IN THE URBAN LANDSCAPE DESIGN}

The application of modern pottery in urban landscape design has its pros and cons, but generally its advantages far outweighs its disadvantages, because modern pottery brings more abundant expressive force for the urban landscape and new expansion for the artistic language expression of urban landscape design . Therefore, we should make rational application of modern pottery in the urban landscape design.

\section{A. Environmental Facilities of Modern Pottery}

In the process of urban development, it is necessary to set a certain number of environmental facilities to serve the public, and these environmental facilities reflects the aesthetic grade and the completion that has become an important content of a city in ethos and public culture. The main urban environmental facilities include fire facilities, health facilities, communications facilities, time keeper, recreational facilities, public visual guidance system, relaxation seat, lighting, etc., which are widely distributed in the public places of a city, such as commercial office area, culture and entertainment area, residential area, squares and so on, with a increasing quantity and variety. Modern pottery not only meet the needs for practicality of environmental facilities, but also bring urban citizens with more artful and comfort sense, to improve the aesthetic value of urban environmental facilities. For example the flower beds, street lamps, trash tanks, planting containers, relaxation seats that are in form of modern pottery are suitable for the surrounding green facilities, giving people a sense of quietness and elegance. Currently modern pottery mainly appears in a small size as the environmental facilities but it has got fast development in the urban landscape design, gradually replacing the materials of wood, steel and stone and becoming a highlight in the urban landscape design [5].

\section{B. Modern Pottery Murals}

Pottery itself has beauty of glaze and texture, together with flexible technique of expression, novel and bold imagination, which provide a broad art space for the creation of pottery mural. Application of pottery murals in urban landscape design can express a unique aesthetic taste and design idea, becoming a unique visual art in urban landscape design. Pottery stroke is part of the building entity, and can make supplementation for the building entity and increase the cultural atmosphere and artistic effect of urban building space. And pottery mural has a unique dignified and straightforward sense, with a large frame and long storage time. Pottery mural has been adopted in many urban landscape designs, and get a good artistic effect. For example, the two pottery murals in the UNESCO headquarters building, "Moon Wall" and "Sun Wall", selected the animals, mythology, the sun, the moon and the stars as the subject matters, and used various glaze, with bold and rough lines and rich and smooth big color lump arranged on the high temperature pottery plate, to show distinct theme an strong arts infection. And these works also used irregular ceramic pieces, avoiding the ceramic surface is too shiny and smooth to affect the entire ceramic mural effect. This also fully indicated that pottery mural has a very strong performance capability, capable of bringing up strong spirit of the times, and having good visual effects and decorative functions, suitable for the application in urban landscape design.

\section{Modern Pottery Sculpture}

Modern pottery sculpture is the perfect combination of traditional pottery and modern urban landscape design, capable of becoming an integral part of the public environment in a city. By refining and selecting the real images in the nature and life to form expression of figurative language, and this formation comes from an intuitive visual experience and a clear image world. The natural properties of pottery clay decide that pottery sculpture has a stronger affinity, with vivid, simple and warm hue, helping to build a warm and natural space art form. Meanwhile, pottery sculpture shortens the distance perception between the urban landscape sculpture and the public, and people can appreciate at short range and touch those sculptures and even can rest and climb on them, creating a harmonious coexistence between man and nature in a city. Beautifying the urban environment, pottery sculpture also reflects a city's spiritual outlook and promotes the construction of urban culture. Therefore, most pottery sculptures are used in the city's public squares, e.g. Foshan Nanzhuang used a series of pottery sculptures to create the city image of "the first town of pottery in China" image of the city, making the city rich of cultural deposits.

Modern pottery sculptures are often used in the urban road construction, especially at the entry and exit of a city, to show the image and style of a city. The two modern 
pottery sculptures in the Jinling Avenue at the entrance of Jingde Town in China, "Rising" and "Raising" have become the landmarks landscape and urban image representatives of Jingde town.

\section{Modern Pottery Masonry}

With the development of technology and the extension of architectural and decorative fields, the architectural and decorative materials of modern pottery came into being, and their natural color and natural texture makes it tremendously popular in modern urban landscape designer. After a certain treatment process, modern pottery masonry has faint highlight, rich shades of grey, warm and dignified and gentle artistic effect, and it also has aging resistance and acid-base resistance, easy for construction and flexible for arrangement, and additionally it has both good aesthetic effect and practical effect. Modern pottery masonry has pristine beauty, by which a unique rural and natural taste can be created, making the urban architectural environment have rich content and form. Modern pottery masonry can also be used to pave and decorate the life paths in a city, such as the pedestrian street, living area, parks, squares, etc. and its comfortable quality and bright and beautiful colors, and various modellings can make people feel comfortable and relaxing in their walking. Due to the diversity of modern pottery masonry in color, texture and pattern, it also has the function of road direction guidance and spatial region division. Active application of modern pottery masonry in urban landscape design enables to break the depressing and dull ambience of ordinary masonry, both meeting the practical needs and creating a gentle, warm, natural and pure artistic effect.

\section{CONCLUSION}

To sum up the above, China's traditional pottery with its profound cultural deposits, has taken top in the global culture, and modern pottery combines Chinese and Western culture with its unique performance practices and techniques, to blend the characteristics of the times full of rich culture into the field of urban landscape design, not only expanding the extension and content of urban landscape design, but also making modern pottery have more practicality and expressiveness. Therefore, urban landscape designers should be fully aware of the characteristics of modern pottery and make reasonable use of modern pottery in urban landscape designs to create a harmonious environmental space, display the image of cities and reflect cultural deposits of cities.

\section{REFERENCES}

[1] Ding Chuanguo, Liu Jianghui. Study on aesthetic value of environmental pottery in landscape design[J]. Jingde Town ceramics. $2011(01)$

[2] Luo Yifeng. The relationship between contemporary pottery and public environment art[J]. Popular Literature. 2011 (04)

[3] Liangbo. Integration and Innovation - Talking about the modern pottery creation in China[J] Chinese ceramics 2011 (04).

[4] $\mathrm{Hu}$ Jinghui. On the Value of environmental pottery in the urban environmental culture construction of Jingde Town[J]. Vicissitudes. $2011(02)$
[5] Jiang Tianyu. On the relation between pottery and public environmental space [J]. Study on Ceramics. 2011 (01) 